\title{
Use of Heteroduplex Mobility Assay for Identification and Differentiation of Phytoplasmas in the Aster Yellows Group and the Clover Proliferation Group
}

\author{
Keri Wang and Chuji Hiruki
}

Graduate Research Assistant and University Professor Emeritus, Department of Agricultural, Food \& Nutritional Science, University of Alberta, Edmonton, Alberta, Canada T6G 2P5. Accepted for publication 5 February 2001.

\begin{abstract}
Wang, K., and Hiruki, C. 2001. Use of heteroduplex mobility assay for identification and differentiation of phytoplasmas in the aster yellows group and the clover proliferation group. Phytopathology 91:546-552.

This paper describes the identification and differentiation of phytoplasmas by a highly sensitive diagnostic technique, DNA heteroduplex mobility assay (HMA). Closely related phytoplasma isolates of clover proliferation $(\mathrm{CP})$, potato witches'-broom (PWB), and alfalfa witches'-broom (AWB) were collected from the field from 1990 to 1999. The entire 16S rRNA gene and 16/23S spacer region were amplified by polymerase chain reaction (PCR) from the field samples and standard $\mathrm{CP}$, $\mathrm{PWB}$, and AWB phytoplasmas and were subjected to restriction fragment length polymorphism (RFLP) analysis and HMA. Two subgroups (I and II) of phytoplasmas in the CP group were identified by HMA but not by RFLP analysis. The results were confirmed by $16 / 23 \mathrm{~S}$ spacer region sequence data analysis. After HMA analyses of the PCR-amplified

16/23S spacer region, 14 phytoplasma isolates from field samples were classified into two aster yellows subgroups: subgroup I, phytoplasma isolates from China aster (Callistephus chinensis) yellows, French marigold (Tagetes patula) yellows, cosmos (Cosmos bipinnatus cv. Dazzler) yellows, clarkia (Clarkia unguiculata) yellows, California poppy (Eschscholzia californica cv. Tai Silk) yellows, monarda (Monarda fistulosa) yellows, and strawflower (Helichrysum bracteatum) yellows; and subgroup II, phytoplasma isolates from zinnia (Zinnia elegans cv. Dahlia Flower) yellows, Queen-Annes-Lace (Daucus carota) yellows, scabiosa (Scabiosa atropurpurea cv. Giant Imperial) yellows, Swan River daisy (Brachycombe multifida cv. Misty Pink) yellows, pot marigold (Calendula officinalis) yellows, purple coneflower (Echinacea purpurea) yellows, and feverfew (Chrysanthemum parthenium) yellows. The results indicate that HMA is a simple, rapid, highly sensitive and accurate method not only for identifying and classifying phytoplasmas but also for studying the molecular epidemiology of phytoplasmas.
\end{abstract}

Phytoplasmas have associated with disease in more than 300 plant species (23) since their discovery in 1967 (12). Inability to culture these organisms in vitro has impeded their detection and characterization. In recent years, phytoplasma diseases have been reported in various vegetables and ornamentals in Canada $(2,15$, $16,21)$. However, most of these disease-associated phytoplasmas have not been identified and their genetic relationship to other phytoplasmas affecting herbaceous ornamentals, vegetables, and forage crops has not been established.

Clover proliferation (CP), potato witches'-broom (PWB), and alfalfa witches'-broom (AWB) are very important diseases and cause severe economic losses each year in Alberta. Since the association of CP with a phytoplasma was first reported (3), the relationship has been studied by nucleic acid hybridization with DNA probes randomly cloned from $\mathrm{CP}$ phytoplasma genomic DNA (8), polymerase chain reaction (PCR) with CP groupspecific primers $(10,18)$, and restriction fragment length polymorphism (RFLP) analyses $(14,21)$ of PCR-amplified highly conserved genes. The above studies have revealed that $\mathrm{CP}, \mathrm{PWB}$, and AWB phytoplasmas are closely related to each other. This raises the question of whether CP, PWB, and AWB are caused by the same phytoplasma strain because all of the previously described techniques cannot differentiate between them. The answer to this question is important for understanding the epidemiology of these diseases and disease management.

Corresponding author: C. Hiruki; E-mail address: chiruki@ afhe.ualberta.ca

Publication no. P-2001-0326-01R

(C) 2001 The American Phytopathological Society
Heteroduplex mobility assay (HMA) is based on the principle that DNA heteroduplexes formed between related sequences have a reduced mobility in polyacrylamide gels proportional to their degree of divergence. Recently, HMA has been reported as a reliable means for identification and classification of phytoplasmas $(1,6,29,30,32)$. The sensitivity of HMA for detecting DNA mutation is higher than any other technique currently available, except for exhaustive DNA sequencing studies $(8,9)$. In this study, HMA analysis of the PCR-amplified $16 / 23 \mathrm{~S}$ spacer region was employed to characterize phytoplasmas associated with ornamental plants and to study genetic diversity of $\mathrm{CP}, \mathrm{PWB}$, and AWB phytoplasmas under field conditions. The analyses resulted in identification of 14 phytoplasmas in subgroups I and II of the aster yellows (AY) group associated with yellows diseases of ornamental plants in Alberta, Canada. To the best of our knowledge, two subgroups of CP, PWB, and AWB phytoplasmas were identified for the first time in field samples.

\section{MATERIALS AND METHODS}

Sources of phytoplasmas. The phytoplasma isolates (from collections in Alberta, Canada and in Germany) used in this study are listed in Table 1. An AY isolate (AY27), a CP isolate, and a PWB isolate, originally collected from diseased field plants in Alberta, were maintained in periwinkle (Catharanthus roseus (L.) Don) in the greenhouse and used as standard representative isolates. An AY phytoplasma isolate from apricot (AYA) was provided by E. Seemüller, Institut für Pflanzenschutz im Obstbau, Dossenheim, Germany. The other isolates were collected in Alberta, Canada as indicated in Table 1. 
Total nucleic acid was extracted from approximately $1 \mathrm{~g}$ of freshly cut midrib tissues of diseased samples as described previously (31). The final pellets were dissolved in $50 \mu \mathrm{l}$ of TrisEDTA buffer (10 mM Tris at $\mathrm{pH} 8.0$ and $1 \mathrm{mM}$ EDTA) and diluted to a final concentration of approximately $20 \mathrm{ng} / \mu \mathrm{l} \mathrm{of}$ nucleic acid with sterile deionized water.

Primer pairs and PCR amplification. PCR assays were used for detection of various phytoplasmas. The somewhat universal primers P1 (11) and P7 (27) were designed on the basis of the $16 \mathrm{~S}$ rDNA sequence of Mollicutes and were expected to amplify the entire 16S rRNA gene together with the $16 / 23 \mathrm{~S}$ spacer region, a DNA fragment approximately $1,800 \mathrm{bp}$ in length.

Amplifications were performed as described previously (31), with $200 \mu \mathrm{M}$ each deoxynucleoside triphosphate (dNTP), $1.0 \mu \mathrm{M}$ each primer, 1.25 units of Taq DNA polymerase (Perkin-Elmer, Branchurg, NJ), and $50 \mathrm{ng}$ of template DNA in a $50-\mu \mathrm{l}$ reaction volume. Thirty-five PCR cycles were conducted in a DNA thermal cycler (2400; Perkin-Elmer Cetus, Norwalk, CT) at the following conditions: denaturation at $94^{\circ} \mathrm{C}$ for $1 \mathrm{~min}$, annealing at $55^{\circ} \mathrm{C}$ for $1 \mathrm{~min}$, and extension at $72^{\circ} \mathrm{C}$ for $2 \mathrm{~min}$. The final extension step was $10 \mathrm{~min}$ at $72^{\circ} \mathrm{C}$ and the reaction mixture was held at $4^{\circ} \mathrm{C}$. Five microliters of the PCR products was analyzed by electrophoresis in a $1.5 \%$ agarose gel, and DNA bands were stained in ethidium bromide and visualized with a UV transilluminator.

Nested PCR. To increase the sensitivity of PCR and to detect potential mixed infections, the primer pairs P3/P7 (27) designed to amplify the $16 / 23 \mathrm{~S}$ spacer region approximately 320 bp in length, and R16F2n/R2 $(13,22)$ designed to amplify the partial 16S rRNA gene approximately $1,200 \mathrm{bp}$ in length, were used for nested
PCR. PCR products amplified by primers P1/P7 were diluted 0 to 100 times in sterile deionized water and were used as templates for a subsequent series of 35 PCR cycles. PCR parameters for primers $\mathrm{R} 16 \mathrm{~F} 2 \mathrm{n} / \mathrm{R} 2$ were the same as previously described. The following parameters were used for primers $\mathrm{P} 3 / \mathrm{P} 7$ : denaturation at $94^{\circ} \mathrm{C}$ for $40 \mathrm{~s}$, annealing at $55^{\circ} \mathrm{C}$ for $45 \mathrm{~s}$, and extension at $72^{\circ} \mathrm{C}$ for $50 \mathrm{~s}$.

RFLP analysis of $16 \mathrm{~S}$ rDNA sequences. The sensitivity of RFLP analysis in differentiating known phytoplasma strains CP, PWB, and AWB was compared with HMA. The partial 16S rDNA sequences $(1.2 \mathrm{~kb})$ amplified by nested PCR using primers $\mathrm{R} 16 \mathrm{~F} 2 \mathrm{n} / \mathrm{R} 2$ were analyzed by restriction endonuclease digestion. Five microliters of each PCR product was digested with the following restriction endonucleases according to the instructions of the manufacturer: AluI, HhaI, HpaII, MseI, RsaI, and Sau3AI (Gibco BRL, Gaithersburg, MD). The restriction products were resolved on a vertical 5\% polyacrylamide gel followed by staining in ethidium bromide. The DNA bands were then visualized with a UV transilluminator. The molecular weights of the fragments were determined by comparison with the 100-bp DNA ladder (BRLLife Technologies, Egenstein, Germany).

HMA analysis of $\mathbf{1 6} / \mathbf{2 3 S}$ spacer region. The $16 / 23 \mathrm{~S}$ spacer region and 16S rRNA gene amplified by nested PCR from CP, PWB, and AWB phytoplasmas were analyzed by HMA. A 4.5- $\mu$ l aliquot of the PCR product amplified from AY27 as a reference was combined with $4.5 \mu$ l of each PCR product amplified from the various $\mathrm{CP}, \mathrm{PWB}$, and $\mathrm{AWB}$ phytoplasma isolates. Then, $1 \mu \mathrm{l}$ of $10 \times$ annealing buffer $(100 \mathrm{mM}$ Tris- $\mathrm{HCl}$ at $\mathrm{pH} 8.0,10 \mathrm{mM}$ EDTA at $\mathrm{pH} 8.0$, and $1 \mathrm{M} \mathrm{NaCl}$ ) was added. One drop of mineral oil was overlaid on the reaction mixture.

TABLE 1. Phytoplasma isolates used in this study

\begin{tabular}{|c|c|c|c|c|}
\hline Isolate & Disease name & Host plant & Year isolated & Reference \\
\hline AWB 1 & Alfalfa witches'-broom & Medicago sativa $\mathrm{L}$. & 1998 & N/A \\
\hline AWB2 & Alfalfa witches'-broom & Medicago sativa $\mathrm{L}$. & 1998 & N/A \\
\hline AWB3 & Alfalfa witches'-broom & Medicago sativa $\mathrm{L}$. & 1998 & N/A \\
\hline AWB4 & Alfalfa witches'-broom & Medicago sativa $\mathrm{L}$. & 1998 & N/A \\
\hline AWB5 & Alfalfa witches'-broom & Medicago sativa $\mathrm{L}$. & 1998 & $\mathrm{~N} / \mathrm{A}$ \\
\hline AWB6 & Alfalfa witches'-broom & Medicago sativa $\mathrm{L}$. & 1998 & N/A \\
\hline AWB7 & Alfalfa witches'-broom & Medicago sativa $\mathrm{L}$. & 1998 & N/A \\
\hline AWB8 & Alfalfa witches'-broom & Medicago sativa $\mathrm{L}$. & 1998 & N/A \\
\hline AWB90 & Alfalfa witches'-broom & Medicago sativa $\mathrm{L}$. & 1990 & N/A \\
\hline AWB92 & Alfalfa witches'-broom & Medicago sativa $\mathrm{L}$. & 1992 & N/A \\
\hline AY27 & Aster yellows & Callistephus chinensis L. & 1976 & $(4)$ \\
\hline AYA & Apricot aster yellows & Prunus armeniaca L. & 1993 & (24) \\
\hline ChAY & China aster yellows & Callistephus chinensis (L.) Nees & 1999 & N/A \\
\hline $\mathrm{ClY}$ & Clarkia yellows & Clarkia unguiculata Lindl., cv. Passion for Purple & 1999 & N/A \\
\hline $\mathrm{CoY}$ & Cosmos yellows & Cosmos bipinnatus Cav., cv. Dazzler & 1999 & N/A \\
\hline $\mathrm{CP}$ & Clover proliferation & Trifolium hybridum L. & 1974 & $(3,5)$ \\
\hline $\mathrm{CP} 1$ & Clover proliferation & Trifolium hybridum L. & 1996 & N/A \\
\hline $\mathrm{CP} 2$ & Clover proliferation & Trifolium hybridum L. & 1996 & N/A \\
\hline $\mathrm{CP} 3$ & Clover proliferation & Trifolium hybridum $\mathrm{L}$. & 1996 & N/A \\
\hline $\mathrm{CP} 4$ & Clover proliferation & Trifolium hybridum $\mathrm{L}$. & 1996 & N/A \\
\hline CP5 & Clover proliferation & Trifolium hybridum $\mathrm{L}$. & 1996 & N/A \\
\hline CP6 & Clover proliferation & Trifolium hybridum $\mathrm{L}$ & 1996 & N/A \\
\hline CPY & California poppy yellows & Eschscholzia californica Cham., cv. Tai Silk & 1999 & N/A \\
\hline FFY & Feverfew yellows & Chrysanthemum parthenium (L.) Bernh & 1999 & N/A \\
\hline FMY & French marigold yellows & Tegetes patula $\mathrm{L}$. & 1999 & N/A \\
\hline MY & Monarda yellows & Monarda fistulosa L. & 1997 & $(31)$ \\
\hline PCY & Purple coneflower yellows & Echinacea purpurea Möench. & 1999 & N/A \\
\hline PMY & Pot marigold yellows & Calendula officinalis $\mathrm{L}$. & 1999 & N/A \\
\hline PWB & Potato witches'-broom & Solanum tuberosum L. & 1974 & (7) \\
\hline PWB1 & Potato witches'-broom & Solanum tuberosum L. & 1996 & N/A \\
\hline PWB2 & Potato witches'-broom & Solanum tuberosum $\mathrm{L}$. & 1996 & N/A \\
\hline PWB3 & Potato witches'-broom & Solanum tuberosum $\mathrm{L}$. & 1996 & N/A \\
\hline PWB4 & Potato witches'-broom & Solanum tuberosum $\mathrm{L}$. & 1996 & N/A \\
\hline PWB5 & Potato witches'-broom & Solanum tuberosum $\mathrm{L}$. & 1996 & N/A \\
\hline QALY & Queen-Annes-Lace yellows & Ammi majus L. & 1999 & N/A \\
\hline $\mathrm{ScY}$ & Scabiosa yellows & Scabiosa atropurpurea L., cv. Giant Imperial & 1999 & N/A \\
\hline SFY & Strawflower yellows & Helichrysum bracteatum $\mathrm{L}$. & 1999 & N/A \\
\hline SRDY & Swan River daisy yellows & Brachycombe multifida (DC.) G.L. Davis, cv. Misty Pink & 1999 & N/A \\
\hline ZY & Zinnia yellows & Zinnia elegans Jacq., cv. Dahlia Flower & 1999 & N/A \\
\hline
\end{tabular}




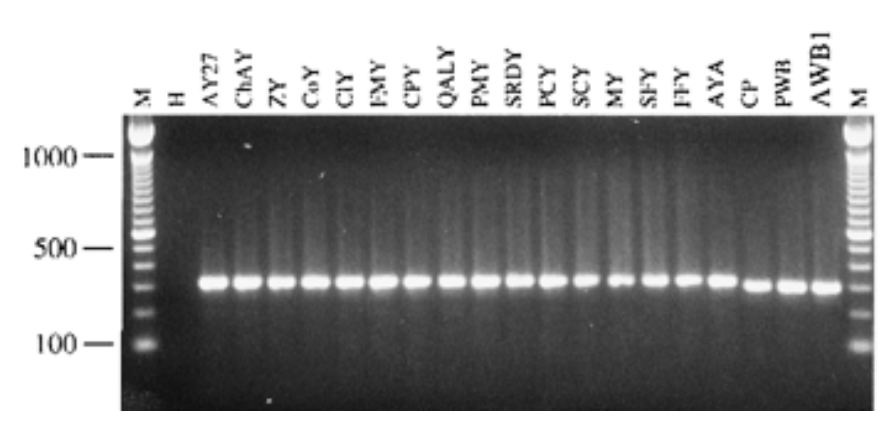

Fig. 1. 16/23S spacer region of phytoplasmas amplified by nested polymerase chain reaction from various phytoplasma isolates using primer pair $\mathrm{P} 3 / \mathrm{P} 7$ and separated by electrophoresis in a 1.5\% agarose gel. M, 100-bp DNA ladder; and H, healthy plant. Aster yellows 27 (AY27), China aster yellows (ChAY), zinnia yellows (ZY), cosmos yellows (CoY), clarkia yellows (ClY), French marigold yellows (FMY), California poppy yellows (CPY), QueenAnnes-Lace yellows (QALY), pot marigold yellows (PMY), Swan River daisy yellows (SRDY), purple coneflower yellows (PCY), scabiosa yellows (SCY), monarda yellows (MY), strawflower yellows (SFY), feverfew yellows (FFY), apricot aster yellows (AYA), clover proliferation (CP), potato witches'-broom (PWB), and alfalfa witches'-broom (AWB1).
After denaturing at $98^{\circ} \mathrm{C}$ for $4 \mathrm{~min}$, the DNA fragments were hybridized on ice. The hybridization products were separated by electrophoresis in a $5 \%$ polyacrylamide gel in $1 \times$ Tris-borateEDTA buffer $(0.088 \mathrm{M}$ Tris-borate, $0.089 \mathrm{M}$ boric acid, and $0.002 \mathrm{M}$ EDTA) at 200 to $250 \mathrm{~V}$ for 3 to $4 \mathrm{~h}$ at room temperature in PROTEAN II (Bio-Rad, Hercules, CA). DNA bands were stained in ethidium bromide and visualized under a UV transilluminator.

To characterize the phytoplasmas associated with ornamental plants, the $16 / 23 \mathrm{~S}$ spacer region amplified from reference phytoplasma strains CP or AY27 was combined with each DNA fragment from the 16/23S spacer region amplified from phytoplasma isolate AYA and from the field samples. All the procedures were the same as described previously.

Nucleotide sequencing. PCR amplified 16/23 spacer region was isolated from a $1 \%$ agarose gel, purified by a gel extraction kit (QIAquick; Qiagen Inc., Mississauga, Ontario, Canada) and directly sequenced with a DYEnamic ET terminator cycle sequencing premix kit (Amersham Pharmacia Biotech Inc., Cleveland). Primers P3 and P7 were used for cycle sequencing both strands of 16/23S spacer region.

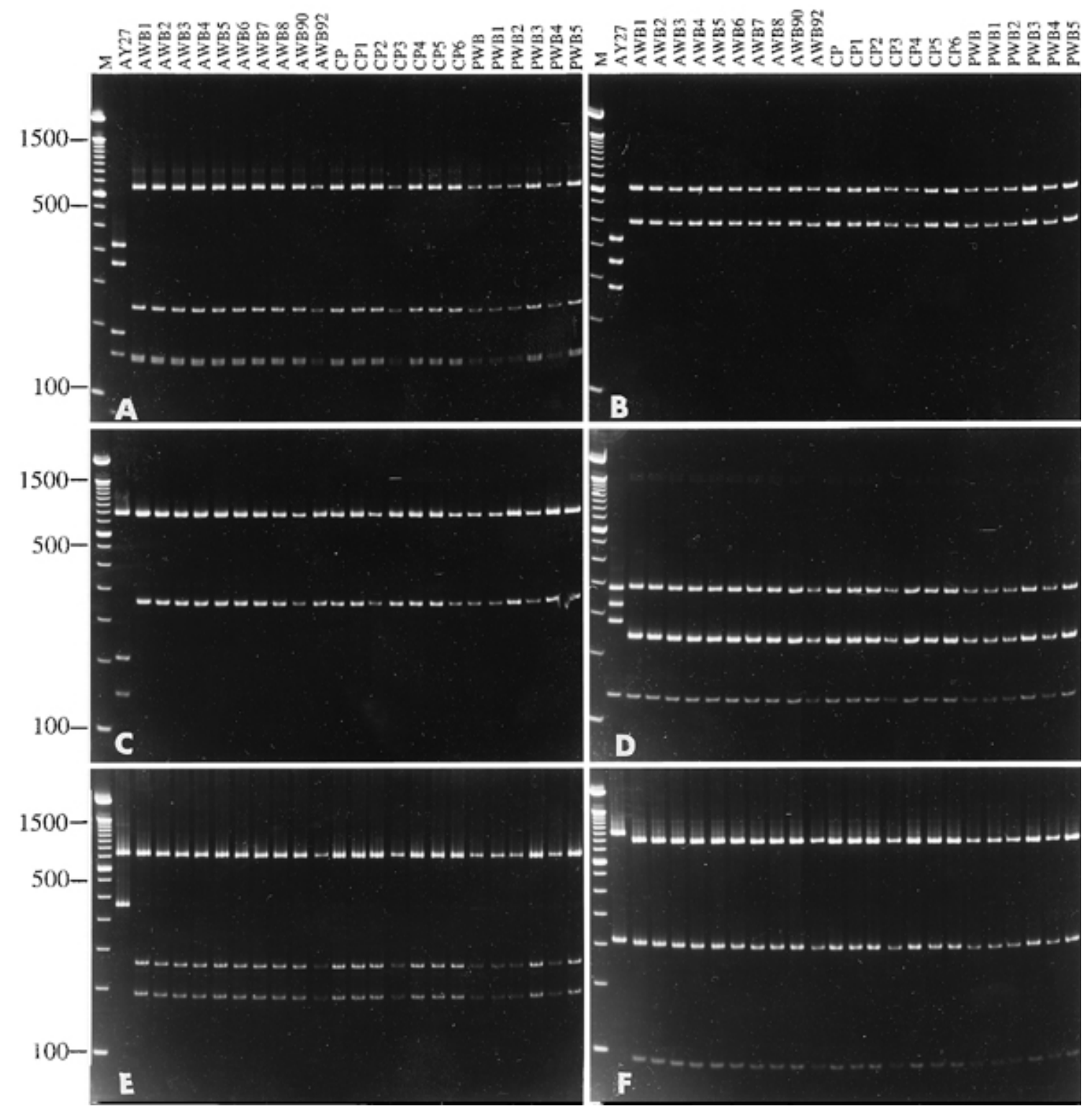

Fig. 2. Restriction fragment length polymorphism analysis of polymerase chain reaction (PCR)-amplified 16S rDNA fragments from various clover proliferation (CP), potato witches'-broom (PWB), and alfalfa witches'-broom (AWB) phytoplasma isolates. PCR products were digested with restriction endonucleases A, AluI; B, RsaI; C, HpaII; D, MseI; E, Sau3AI; and F, HhaI. The restriction products were subjected to electrophoresis in a 5\% polyacrylamide gel. M, 100-bp DNA ladder; and AY27, aster yellows 27. 


\section{RESULTS}

Detection of phytoplasmas in diseased ornamental plants. Direct PCR and nested PCR were employed to detect phytoplasmas in field samples of ornamental plants collected in Alberta in 1999. For direct PCR with primer pair P1/P7, a DNA fragment approximately $1.8 \mathrm{~kb}$ in size was amplified from all samples showing yellows or witches'-broom symptoms. No DNA bands were amplified from the healthy control. Weak bands were observed with field samples of zinnia, cosmos, clarkia, and scabiosa (data not shown). Therefore, following primary amplification, the PCR products were subjected to nested PCR amplification using primers $\mathrm{P} 3 / \mathrm{P} 7$ to increase the sensitivity of the PCR and the yield of PCR products for further analyses. DNA fragments, approximately $320 \mathrm{bp}$ in length, were amplified from all diseased samples but not from the healthy control (Fig. 1). Similar DNA fragments were consistently amplified from all other phytoplasma samples used as references in this study by both direct PCR and nested PCR using primers P3/P7.

Finer differentiation of CP phytoplasmas by HMA compared with RFLP analysis. To compare the sensitivity of HMA and RFLP in detecting genetic divergences of phytoplasma isolates collected from the field, the $16 \mathrm{~S}$ rRNA gene amplified from all $\mathrm{CP}, \mathrm{AWB}$, and PWB phytoplasma isolates was analyzed by both HMA and RFLP. In the RFLP analysis of the 16S rRNA gene, the results repeatedly showed that the RFLP profiles of all field samples and standard isolates of CP, PWB, and AWB were identical for all restriction enzymes tested (Fig. 2). However, when the same PCR products $(1.2 \mathrm{~kb})$ were analyzed by HMA
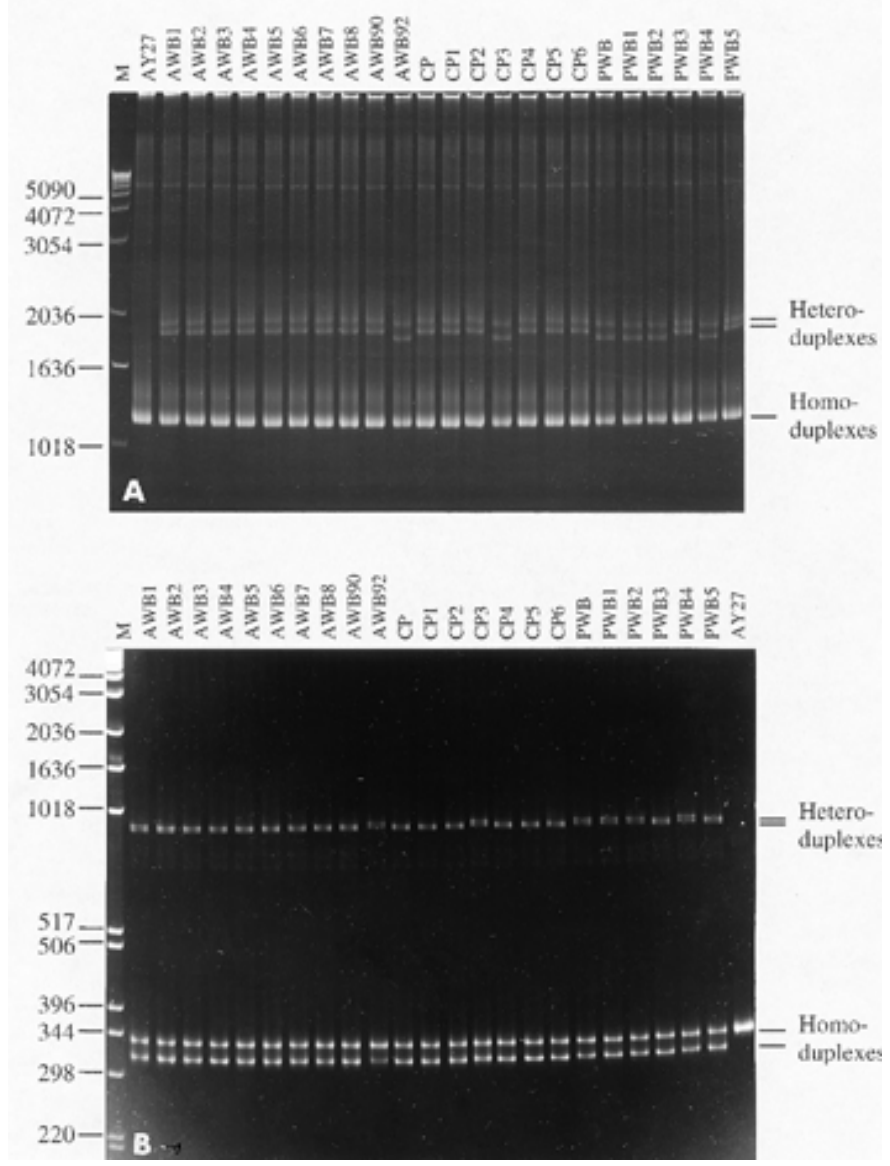

Fig. 3. Heteroduplex mobility assay analysis of $\mathbf{A}$, nested polymerase chain reaction (PCR)-amplified 16S rRNA gene and $\mathbf{B}, 16 / 23 \mathrm{~S}$ spacer region from clover proliferation (CP), potato witches'-broom (PWB), and alfalfa witches'broom (AWB) phytoplasma isolates. Heteroduplexes and homoduplexes were separated by electrophoresis in a 5\% polyacrylamide gel. Aster yellows 27 (AY27) was used as a reference. M, 1-kb DNA ladder. using AY27 as a reference, DNA heteroduplex bands at approximately $1,800 \mathrm{bp}$ in addition to the homoduplex bands at approximately $1,200 \mathrm{bp}$, were observed in a polyacrylamide gel (Fig. 3A). No heteroduplex band was observed for the combination of AY27 $\times$ AY27. DNA heteroduplexes formed by 16S rDNA fragment combinations of AY27 and AWB92, CP3, PWB, PWB1, PWB2, or PWB4 migrated faster than those formed by other combinations. The results indicated that the closely related phytoplasmas were successfully differentiated by HMA but not by RFLP analysis.

The 16/23S spacer regions amplified from all phytoplasma isolates of AWB, CP, and PWB were subjected to HMA using AY27 as a reference. Heteroduplex bands at approximately $900 \mathrm{bp}$ were observed for all AWB, CP, and PWB isolates but not for AY27. Similar to the results obtained with HMA profiles by the $1.2-\mathrm{kb}$ 16S rDNA fragment amplified by nested PCR, HMA profiles of $16 / 23 \mathrm{~S}$ spacer region revealed that the heteroduplex mobilities of AWB92 and CP3 and PWB, PWB1, PWB2, and PWB4 were identical to each other but differed from the remaining isolates of CP, PWB, and AWB (Fig. 3B). Therefore, two subgroups of phytoplasma isolates of $\mathrm{AWB}, \mathrm{CP}$, and $\mathrm{PWB}$ were identified on the basis of HMA profiles of the $16 / 23 \mathrm{~S}$ spacer region and $16 \mathrm{~S}$ rRNA gene. Phytoplasma isolates AWB1 to AWB8, AWB90, CP, $\mathrm{CP} 1, \mathrm{CP} 2, \mathrm{CP} 4$ to $\mathrm{CP} 6, \mathrm{PWB} 3$, and PWB5 were classified as $\mathrm{CP}$ subgroup I whereas AWB92, CP3, PWB, PWB1, PWB2, and PWB4 were classified as CP subgroup II. Neither subgroup corresponded with any of the three diseases, because each disease was represented unevenly by phytoplasmas belonging to both HMA groups.

Because the 16/23S spacer regions of AY27 and CP, PWB, and AWB are different in length, two homoduplex bands were observed for the $16 / 23 \mathrm{~S}$ spacer genes. The homoduplex band at approximately 320 bp represents the 16/23S spacer region of AY27, whereas the band at approximately 300 bp represents those of $\mathrm{CP}$, PWB, and AWB.

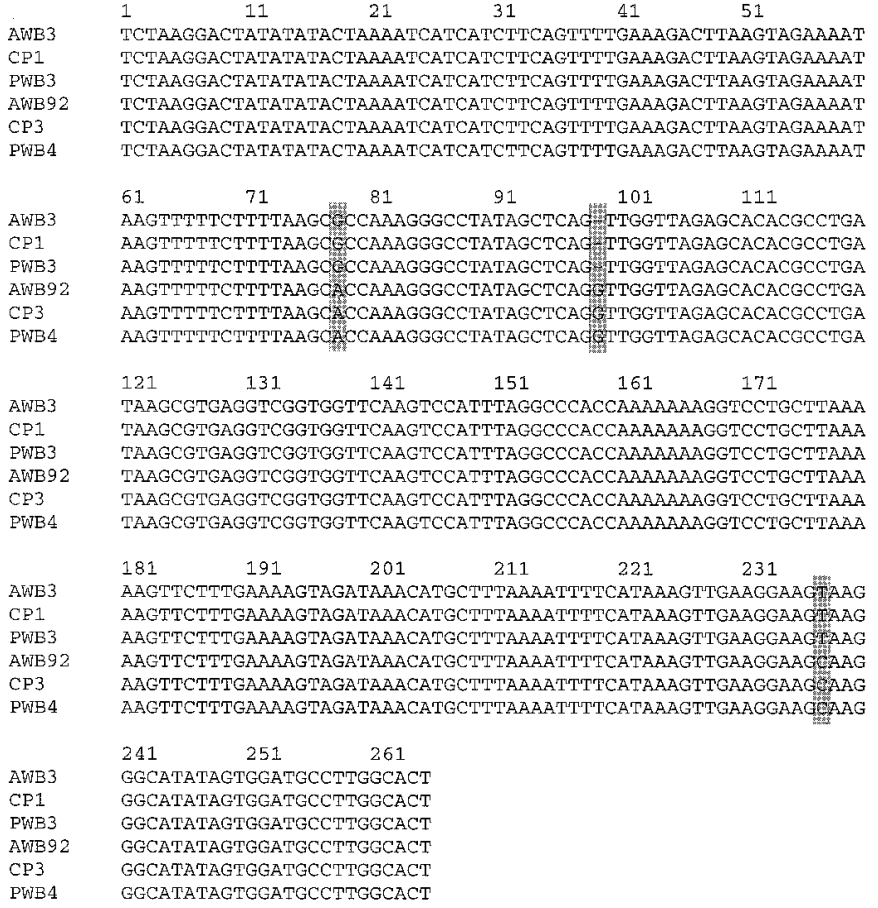

Fig. 4. Nucleotide sequences of the $16 / 23 \mathrm{~S}$ spacer region of alfalfa witches'broom (AWB), clover proliferation (CP), and potato witches'-broom (PWB) phytoplasmas. The nucleotide sequences of primers P3 and P7 are not included. Phytoplasma isolates of AWB3, CP1, and PWB3 were classified as members of $\mathrm{CP}$ subgroup I, whereas AWB92, CP3, and PWB4 were classified as members of CP subgroup II. 
Nucleotide sequence of the 16/23S spacer regions of AWB, CP, and PWB phytoplasmas. The approximately 265-bp sequence of the 16/23-spacer region amplified from AWB, CP, and PWB phytoplasmas was determined by directly sequencing both strands (Fig. 4). Analysis of the sequence alignment data revealed that members of CP subgroup I (AWB3, CP1, and PWB3) had identical sequences that differed from those of $\mathrm{CP}$ subgroup II (AWB92, CP3, and PWB4) at positions 78, 99, and 237. The sequence data agree with the results obtained by HMA.

Identification and classification of phytoplasmas associated with ornamental plants. Heteroduplexes were formed by combining the 16/23S spacer region amplified from $\mathrm{CP}$ and each of the corresponding DNA fragments from the phytoplasmas associated with ornamental plants (Figs. 5 and 6). The phytoplasma isolates from diseased ornamental plants were classified into two AY subgroups by HMA. China aster yellows (ChAY), French marigold yellows (FMY), cosmos yellows (CoY), clarkia yellows (ClY), California poppy yellows (CPY), monarda yellows (MY), and strawflower yellows (SFY) phytoplasmas showed heteroduplex mobilities similar to AY27 when CP was used as a reference and, therefore, were classified as new members of subgroup I together with AY27 (Fig. 5). Phytoplasma isolates Queen-Annes-Lace yellows (QALY), scabiosa yellows (ScY), pot marigold yellows (PMY), Swan River daisy yellows (SRDY), purple coneflower yellows (PCY), zinnia yellows (ZY), and feverfew yellows (FFY) showed HMA profiles identical to each other but different from AY27 and were classified as AY subgroup II (Fig. 5). Having a unique heteroduplex mobility, phytoplasma strain AYA was distinguishable from all members of the two AY subgroups tested in this study. Similar results were obtained when AY27 was used as the reference (Fig. 6). However, the heteroduplexes formed between phytoplasmas AYA and AY27 had very similar mobilities to those formed between AY27 and AY subgroup II (Fig. 6).

\section{DISCUSSION}

Phytoplasmas have been classified into 20 major groups on the basis of sequence analysis of the 16S rRNA gene (25). A total of

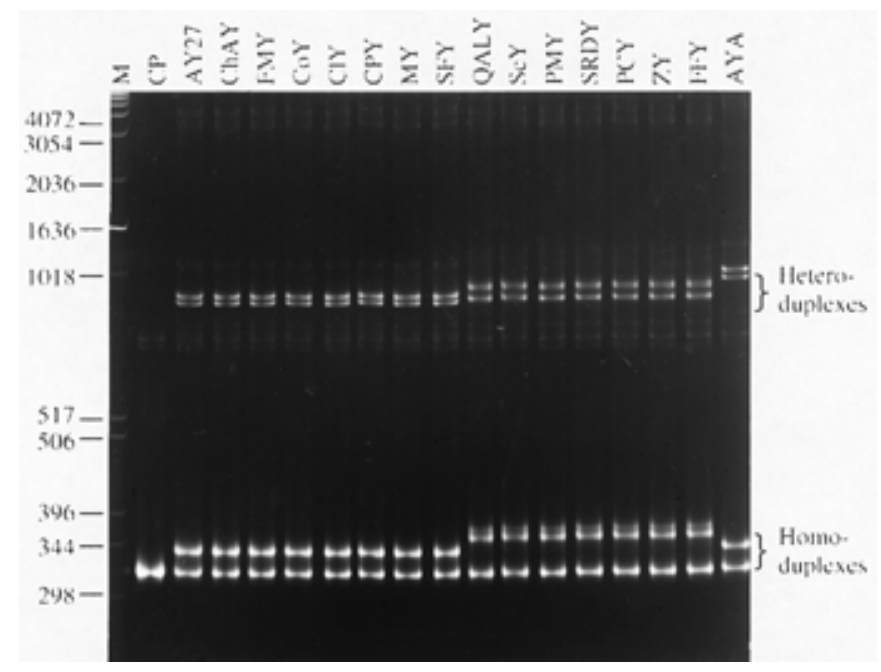

Fig. 5. Heteroduplex mobility assay analysis of nested polymerase chain reaction-amplified 16/23S spacer region from various phytoplasma associated with ornamental plants. Heteroduplexes and homoduplexes were separated by electrophoresis in a 5\% polyacrylamide gel. Clover proliferation (CP) was used as a reference. M, 1-kb DNA ladder. Aster yellows 27 (AY27), China aster yellows (ChAY), French marigold yellows (FMY), cosmos yellows (CoY), clarkia yellows (CIY), California poppy yellows (CPY), monarda yellows (MY), strawflower yellows (SFY), Queen-Annes-Lace yellows (QALY), scabiosa yellows ( $\mathrm{ScY}$ ), pot marigold yellows (PMY), Swan River daisy yellows (SRDY), purple coneflower yellows (PCY), zinnia yellows (ZY), feverfew yellows (FFY), and apricot aster yellows (AYA).
246 phytoplasmas have been assigned to 20 major groups on the basis of molecular or serological analyses. The AY group is the largest major group, and includes more than 100 phytoplasma isolates. In this study, four phytoplasma isolates from FMY, CoY, $\mathrm{ClY}$, and CPY were identified as members of AY subgroup I and the other four phytoplasma isolates from ZY, QALY, ScY, and SRDY were identified as members of AY subgroup II.

PMY and PCY were found to be associated with phytoplasmas by electron microscopy in Canada in $1997(15,16)$. However, the genetic identity of the pathogen was not established at that time. We determined that PMY phytoplasma belongs to AY subgroup II. Previous RFLP analysis of the 16S rDNA fragment amplified from PCY phytoplasma by four restriction enzymes (AluI, HhaI, $R s a \mathrm{I}$, and Sau3AI) showed restriction patterns identical to those of AY27 (19,28). In the present study, HMA profiles of the $16 / 23 \mathrm{~S}$ spacer region indicated that PCY is different from AY27 and belongs to AY subgroup II. This discrepancy may be due to the inability of RFLP to differentiate PCY from AY27. However, the existence of different types of phytoplasmas in samples from different origins cannot be excluded because different samples were used in these studies.

In this study, we demonstrated that HMA is a highly sensitive diagnostic technique for the differentiation and identification of phytoplasmas. The closely related phytoplasma isolates of $\mathrm{CP}$, PWB, and AWB were not differentiated by RFLP with the restriction endonucleases used in this study. These results are consistent with previous studies in which $\mathrm{CP}, \mathrm{PWB}$, and AWB phytoplasmas were classified in the same phylogenetic group based on their identical RFLP profiles $(14,17,18,21,22)$. However, genetic differences between $\mathrm{CP}, \mathrm{PWB}$, and AWB phytoplasma isolates were clearly discerned by HMA with the $16 / 23 \mathrm{~S}$ spacer region or the $16 \mathrm{~S}$ rRNA gene. The results provide evidence that HMA is much more sensitive than RFLP analysis in differentiating closely related phytoplasma isolates. The sensitivity of HMA in detecting DNA mutations of phytoplasmas also was demonstrated in previous studies in which a single base pair insertion/deletion or two base pair substitutions in a 500-bp DNA fragment were easily detected $(29,30)$.

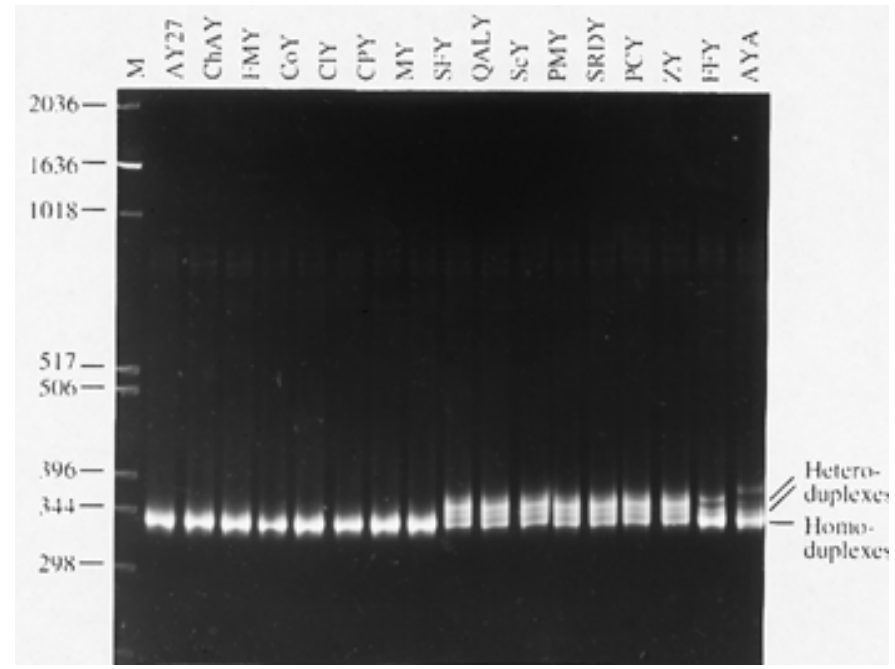

Fig. 6. Heteroduplex mobility assay analysis of nested polymerase chain reaction-amplified 16/23S spacer region from various phytoplasma isolates associated with ornamental plants. Heteroduplexes and homoduplexes were separated by electrophoresis in a 5\% polyacrylamide gel. Aster yellows 27 (AY27) was used as a reference. M, 1-kb DNA ladder. China aster yellows (ChAY), French marigold yellows (FMY), cosmos yellows (CoY), clarkia yellows (ClY), California poppy yellows (CPY), monarda yellows (MY), strawflower yellows (SFY), Queen-Annes-Lace yellows (QALY), scabiosa yellows (ScY), pot marigold yellows (PMY), Swan River daisy yellows (SRDY), purple coneflower yellows (PCY), zinnia yellows (ZY), feverfew yellows (FFY), and apricot aster yellows (AYA). 
In this study, two subgroups of AWB, CP, and PWB phytoplasmas were identified, to our knowledge for the first time, by HMA. Phytoplasmas of both types can cause witches'-broom of alfalfa and potato plants and proliferation of clover plants. The differences between these two subgroups were confirmed by sequence data that showed three single-base pair differences in the $16 / 23 \mathrm{~S}$ spacer region between subgroups I and II. These results support a notion that two different populations of phytoplasmas belonging to $\mathrm{CP}$ subgroups I and II occur in $\mathrm{CP}, \mathrm{PWB}$, and $\mathrm{AWB}$ diseases in Alberta.

Our study clearly indicates that HMA is more accurate than RFLP analysis for the classification of phytoplasmas. Although RFLP analyses of highly conserved genes have been useful in constructing a phylogenetic tree of phytoplasmas, RFLP analysis relies on the presence or absence of restriction sites in a DNA fragment and a set of restriction enzymes must be used $(13,14,22)$. DNA sequence analyses for more than 20 phytoplasma isolates in previous studies have indicated that RFLP-based classification of phytoplasmas in certain groups does not fully coincide with the phylogenetic relationships of the organisms based on DNA sequences $(20,26)$. For example, strain AYA and other typical AY strains that were classified in two different major groups by RFLP analyses (24) were found to share sequence homology at a level as high as $99 \%$ in the $16 \mathrm{~S}$ rRNA gene (27). In this study, the $16 / 23 \mathrm{~S}$ spacer region of AYA phytoplasma had a unique heteroduplex mobility that was different from that of AY27 (Fig. 5), and thus AYA may be classified as a member of a new AY subgroup, which fully agrees with the results of sequence analysis of the $16 \mathrm{~S}$ rRNA gene.

Use of different standard phytoplasma strains as references in HMA can increase the sensitivity for detecting minor differences between phytoplasma isolates. In this study, the heteroduplex mobility of AYA was very similar to those of QALY, ScY, PMY, SRDY, PCY, ZY, and FFY when AY 27 was used as a reference (Fig. 6). However, the differences between AYA and others were clearly observed by HMA when $\mathrm{CP}$ was used as a reference (Fig. 5). This suggests that two or more references should be used when attempting to differentiate similar phytoplasmas or to detect minor mutations of phytoplasmas.

In conclusion, our results suggest that HMA may offer a useful method for studying the genetic diversity and molecular epidemiology of phytoplasmas by monitoring DNA sequence diversity of a given phytoplasma population and tracking the evolution of the phytoplasmas.

\section{ACKNOWLEDGMENTS}

This research was supported by the Natural Sciences and Engineering Council of Canada (Grant A3843). We thank E. Seemüller for providing phytoplasma DNAs.

\section{LITERATURE CITED}

1. Ceranic-Zagorac, P., and Hiruki, C. 1996. Comparative molecular studies on aster yellows phytoplasmas. Acta Hortic. 432:266-276.

2. Chang, K. F., Hwang, S. F., and Mirza, M. 1995. Mycoplasma-like organisms associated with phyllody of Brassica chinensis L. Zeit. J. Plant Dis. Prot. 102:144-150.

3. Chen, M. H., and Hiruki, C. 1975. Electron microscopy of mycoplasmalike bodies associated with clover proliferation disease. Proc. Am. Phytopathol. Soc. 2:52.

4. Chen, M.-H., and Hiruki, C. 1977. Effects of dark treatment on the ultrastructure of the aster yellows agent in situ. Phytopathology 67: 321-324.

5. Chen, M. H., and Hiruki, C. 1978. Occurrence of tubular structures in Vinca rosea infected with the Alberta isolate of the aster yellows agent. Protoplasma 95:207-216.

6. Cousin, M.-T., Roux, J., Boudon-Padieu, E., Berges, R., Seemüller, E., and Hiruki, C. 1998. Use of heteroduplex mobility analysis (HMA) for differentiating phytoplasma isolates causing witches'-broom disease on Populus nigra cv. italica and stolbur or big bud symptoms on tomato. J.
Phytopathol. 146:97-102.

7. da Rocha, A., Ohki, S. T., and Hiruki, C. 1986. Detection of mycoplasmalike organisms in situ by indirect immunofluorescence microscopy. Phytopathology 76:864-868.

8. Delwart, E., Sheppard, H. W., Walker, B. D., Goudsmit, J., and Mullins, J. I. 1994. Human immunodeficiency virus type 1 evolution in vivo tracked by DNA heteroduplex mobility assays. J. Virol. 68:6672-6683.

9. Delwart, E. L., Shpaer, E. G., Louwagie, J., Mccutchan, F. E., Grez, M., Rubsamen-Waigmann, H., and Mullins, J. I. 1993. Genetic relationships determined by a DNA heteroduplex mobility assay: Analysis of HIV-1 env Genes. Science 262:1257-1261.

10. Deng, S., and Hiruki, C. 1990. Enhanced detection of a plant pathogenic mycoplasmalike organism by polymerase chain reaction. Proc. Japan Acad. 66B:140-144.

11. Deng, S., and Hiruki, C. 1991. Amplification of 16S rRNA genes from culturable and non-culturable mollicutes. J. Microbiol. Methods 14: 53-61.

12. Doi, Y., Teranaka, M., Yora, K., and Asuyama, H. 1967. Mycoplasma or P.L.T. group-like microorganisms found in the phloem elements of plants infected with mulberry dwarf, potato witches'-broom, aster yellows or paulownia witches'-broom. Ann. Phytopathol. Soc. Jpn. 33:259-266.

13. Gundersen, D. E., and Lee, I.-M. 1996. Ultrasensitive detection of phytoplasmas by nested-PCR assays using two universal primer pairs. Phytopathol. Mediterr. 35, 144-151.

14. Gundersen, D. E., Lee, I.-M., Rehner, S. A., Davis, R. E., and Kingsbury, D. T. 1994. Phylogeny of mycoplasmalike organisms (phytoplasmas): A basis for their classification. J. Bacteriol. 176:5244-5254.

15. Hwang, S. F., Chang, K. F., Howard, R. J., and Blade, S. F. 1997. Yellows diseases of calendula (Calendula officinalis) and valerian (Valeriana officinalis) in Alberta, Canada, associated with phytoplasma infection. J. Plant Dis. Prot. 104:452-458.

16. Hwang, S. F., Chang, K. F., Howard, R. J., Khadhair, A. H., Gaudiel, R. G., and Hiruki, C. 1997. First report of a yellows phytoplasma disease in purple coneflower (Echinacea spp.) in Canada. J. Plant Dis. Prot. 104:182-192.

17. Khadhair, A. H., and Hiruki, C. 1995. The molecular genetic relatedness of willow witches'-broom phytoplasma to the clover proliferation group. Proc. Japan Acad. 71B:145-147.

18. Khadhair, A. H., Hiruki, C., and Hwang, S. F. 1997. Molecular detection of alfalfa witches'-broom phytoplasma in four leafhopper species associated with infected alfalfa plants. Microbiol. Res. 152:269-275.

19. Khadhair, A. H., Hwang, S. F., Chang, K. F., and Howard, R. J. 1997. Molecular identification of aster yellows phytoplasma in purple coneflower and monarda based on PCR amplification and RFLP analyses of 16S rDNA sequences. J. Plant Dis. Prot. 104:403-410.

20. Kuske, C. R., and Kirkpatrick, B. C. 1992. Phylogenetic relationships between the western aster yellows mycoplasmalike organism and other prokaryotes established by $16 \mathrm{~S}$ rRNA gene sequence. Int. J. Syst. Bacteriol. 42:226-233.

21. Lee, I.-M., Davis, R. E., and Hiruki, C. 1991. Genetic interrelatedness among clover proliferation mycoplasmalike organisms (MLOs) and other MLOs investigated by nucleic acid hybridization and restriction fragment length polymorphism analyses. Appl. Environ. Microbiol. 57:3565-3569.

22. Lee, I.-M., Hammond, R. W., Davis, R. E., and Gundersen, D. E. 1993. Universal amplification and analysis of pathogen 16S rDNA for classification and identification of mycoplasmalike organisms. Phytopathology 83:834-842.

23. McCoy, R. E., Caudwell, A., Chang, C. J., Chen, T. A., Chiykowski, L. N., Cousin, M. T., Dale, J. L., de Leeuw, G. T. N., Golino, D.A., Hackett, K. J., Kirkpatrick, B. C., Marwitz, R., Petzold, H., Sinha, R. C., Sugiura, M., Whitcomb, R. F., Yang, I. L., Zhu, B. M., and Seemüller, E. 1989. Plant diseases associated with mycoplasmalike organisms. Pages 545560 in: The Mycoplasmas, Vol. 5. R. F. Whitcomb and J. G. Tully, eds. Academic Press, New York.

24. Schneider, B., Ahrens, U., Kirkpatrick, B. C., and Seemüller, E. 1993. Classification of plant-pathogenic mycoplasma-like organisms using restriction-site analysis of PCR-amplified 16S rDNA. J. Gen. Microbiol. 139:519-527.

25. Seemüller, E., Marcone, C., Lauer, U., Ragozzino, A., and Goschl, M. 1998. Current status of molecular classification of the phytoplasmas. J. Plant Pathol. 80:3-26.

26. Seemüller, E., Schneider, B., Maurer, R., Ahrens, U., Daire, X., Kison, H., Lorenz, K.-H., Firrao, G., Avinent, L., Sears, B. B., and Stackebrandt, E. 1994. Phylogenetic classification of phytopathogenic mollicutes by sequence analysis of $16 \mathrm{~S}$ ribosomal DNA. Int. J. Syst. Bacteriol. 44: 440-446.

27. Smart, C. D., Schneider, B., Blomquist, C. L., Guerra, L. J., Harrison, N. A., Ahrens, U., Lorenz, K. H., Seemüller, E., and Kirkpatrick, B. C. 1996. Phytoplasma-specific PCR primers based on sequences of the 16- 
23S rRNA spacer region. Appl. Environ. Microbiol. 62:2988-2993.

28. Stanosz, G. R., Heimann, M. F., and Lee, I.-M. 1997. Purple coneflower is a host of the aster yellows phytoplasma. Plant Dis. 81:424.

29. Wang, K., and Hiruki, C. 1999. Rapid detection of a single-base-pair mutation in phytoplasmal conserved genes by DNA heteroduplex mobility assay (HMA). Proc. Japan Acad. 75B:259-262.

30. Wang, K., and Hiruki, C. 2000. Heteroduplex mobility assay (HMA) detects DNA mutations for differentiation of closely related phytoplasma strains. J. Microbiol. Methods 41:59-68.

31. Wang, K., Hiruki, C., and Chen, M. H. 1998. Identification of a phytoplasma causing yellows of Monarda. Plant Pathol. 47:103-106.

32. Zhong, Q., and Hiruki, C. 1994. Genetic differentiation of phytoplasma isolates determined by a DNA heteroduplex mobility assay. Proc. Japan Acad. 70B:127-131. 